\title{
Immigrants and Migration Policy during François Mitterrand's Reign
}

\author{
Razita Inayah Kiasatina ${ }^{1}$ and Airin Miranda ${ }^{2}$ \\ ${ }^{1}$ French Departement, Faculty of Humanities \\ ${ }^{2}$ Universitas Indonesia \\ ${ }^{1}$ razitainayahh@gmail.com, 22airin_pane@yahoo.com
}

\begin{abstract}
The presence of immigrants from Africa in France began after World War II to rebuild France. Begin in the 1940s, the number of immigrants continued to increase and most of them came from the Maghreb countries. The high number of non-EU immigrants triggered social problems in France which later developed into Islamophobia. Also in the economic area, the number of unemployed in France was increasing caused by low skilled Maghreb immigrants. The immigrant problem was noticed by France in the 1980s, when François Mitterrand was elected as the Socialist President who ruled France for the first time in two periods. This study was conducted using qualitative methods to describe the development of the migration policy of François Mitterrand's government. The socialist style of government tends to be moderate to immigrants, while the right government has firmer measures. The finding of this article shows that the migration policy during the reign of François Mitterrand is ineffective because the number of illegal immigrants living in France keeps increasing and the process of integration between the two parties was difficult
\end{abstract}

Keywords: migration policy, François Mitterrand, integration, immigrants in France

\section{INTRODUCTION}

After the World War I, the workforce in France reduced. In overcoming this problem, the French government welcoming foreigners to work in France. In order to recruiting foreign workers, The Office National de l'immigration (National Office of Immigration) policy implemented easy requirements. This policy increases the number of immigrants in France, which later brought problems in France and other Western European countries [1]. Until this day, the immigrant problem is still in the process of being resolved, not only in France but also in several other EU countries. For this reason, it is necessary to look at the migration policy in the 1980s, because at that time it was the starting point of the increasing number of immigrant populations in France, which was regulated through migration policy. [2] In the late 1980s, the issue of immigration in France became a topic of attention and debate.

This study focuses on the reign of François Mitterrand that was marked by a massive and illegal influx of immigrants, thus becoming the starting point for determining the number of immigrant populations in France. For this reason, it is important to look at the impact of migration policy and the efforts of the François Mitterrand's government in helping 
immigrants to integrate with French society. The purpose of this study is to explain the impact of the migration policy during the reign of François Mitterrand and the process of immigrant integration in France at that time.

\section{METHOD}

The method used in this study is a qualitative research and historical method. Qualitative research was used to explore and understand the meaning of beings and social problems [3] The data obtained by this method are related to François Mitterrand's government, French's left-wing politic, the condition of immigrants in France and their difficulty to integrate with French society. To further seen the impact of Mitterrand's reign, this study need in-depth research by collecting historical sources systematically to produce synthèseresults (generally written) that are useful for understanding historical reality. Historical method helps to evaluate how well the impact by François Mitterrand's government and the left-wing politic in helping immigrants to integrate with French society, that was seen in the social and cultural conditions of immigrants in France. Data sources that will be used in this study are; journal articles, news articles, books, and statistical data relating to migration policy in France, François Mitterrand politics, and immigrant integration in France.

\section{RESULT AND DISCUSSION}

Tiersky (1995) analyze that Mitterrand was elected as the first Socialist President in Republic V on May 10th, 1981 which was later considered to be an important inheritance ever obtained from left-wing politics. [4] François Mitterrand's political career already began from Republic IV. He continued to be President of France for 2 periods, which made him the longest President of Republic V in history.[2] The new president's policy agenda embodied an ambitious reform program, Mitterrand claimed, his government would precipitate a "rupture" with capitalism, and lay the foundations for a "French road to socialism." [14] The PartiSocialistebelieve in nationalizations, a strong welfare state, and participative democracy. Meanwhile, the main "conservative" party, the right-wing is a party that encompasses traditional conservatives, social liberals, or neo-conservative right. [15] The left and rightwing politics have different characteristics, in the non-EU immigrant issues, both parties tend to reject their presence in France. In applying its policies, we will see that socialists are more tolerant and tend to support the human right by providing remission in their policies compared to conservatives.

\subsection{Regulation of May 1981}

On May 27th, 1981, the Ministry ofinternal affairs, Gaston Defferre provide remission to immigrants, through the ONI (Office National de l'immigration) which delay the expulsion of immigrants and keep immigrants who are born in France or children who lived in France before ten-year-old. Also, there is a regularization program that permits temporary residence to all immigrants including those who are illegal. [5] This regulation showed the tolerant character of the Socialists, which is in line with Mitterrand's goal of upholding human rights.

\subsection{Regulation of July 1981}

Then on July 6th, 1981, immigrants who disturbed public order were threatened to be banished from France. This policy reconsideredthe case of expulsion of immigrants and provide three-month temporary resident cards for immigrants who request them, including 
those who are illegal and give permission for marriages of foreigners from certain countries. As a result, in 1981-82, many workers applied to obtain a residence permit or work permit. [5] But to stop immigration, Chirac and Barre, right-wing politic figures, want to stop family reunification by refusing visas and banishing family members. Mauroy, left-wing political figure, had a different approach, providing an opportunity for everyone who came to France before January 1981 to give a temporary residence permit. [13] Chirac and Barre was considered to be more effective because theymanaged to reduce illegal foreign workers.

\subsection{Regulation of October 1981}

The law of October 29th, 1981 regulates the legal process of immigrants in France and provides guarantees for immigrants by not banishing them under certain conditions. These conditions include immigrants who have lived in France before the age of adulthood (under 18-year-old), or who lived in France more than 15 years, who are paired (at least 6 months) with a French citizen, parents of French children (at least one of them lives in France).INSEE study showed that immigrants who were born in Maghreb more often have parents who have not attended school: $42 \%$ compared to $21 \%$ with immigrant parents from Spain, Portugal or Italy.

A research from INSEE that shows the distribution of immigrants by country of birth and the evolution of the number of immigrants by country of origin, show that half of the immigrants who lived in France in 2008 came before 1987, when Mitterrand was President of France. In summary, the number of non-EU immigrants is a lot more than the number of EU immigrants. Especially in the year of 1982, 1990 and 1999 when Mitterrand influenced France. [6]

The October 29th, 1981 also regulates the conditions of foreign workers in France by providing strict measures against employers who recruit illegal immigrant workers and remove work permits for refugees and eliminate the quota of employees for foreigners. In late 1982, the socialist government emphasized controlling the flow of migration and deporting them to the border. [7] This makes it difficult for illegal immigrants to find a job because companies are not allowed to recruit them even at a low price.

Despite the difficulty of illegal immigrants, the socialist government gave temporary work permission for high school students to work in the 1982-83 academic year. The right to work was granted unconditionally, because of bilateral agreements, with students from Portugal, Algeria, Zaire, the Central African Republic, Gabon, and Togo, and for students with political refugee status. [5] This proves Mitterrand's success in his relations with other countries. Education is considered as social mobility, so schools are the main instruments and symbols of the French integration model; l'écolerépublicaine this shows that the socialist government gives every child the right to education, even if their parents are illegal immigrants. [6]

\subsection{Regulation of July 1984}

The government finally recognized the presence of immigrants by making resident cards to those who had permanent jobs and lived in France for more than three years. This resident card is valid for ten years and can be renewed, immigrants also have the right to receive training in their chosen professional fields. In the field of education, as an effort to integrate and fight inequality access to education, the French government implement a priority education zone policy (Zone Education Prioritaire) initiated by the then French Minister of Education, Alain Savary in 1981. [7]

Based on INSEE statistical data for the period 1982-1992 it appears that the policy did not resolve the issue of inequality. Many immigrant students do not complete their education or even choose not to go to school. [8] Research by Sayad in 1991 emphasized the fact that the 
educational ambitions for most Algerian families did not guarantee the success of their children in school if their parents do not have a high level of education and do not have a familiarity with French culture.

The Socialist Government is also trying to harmonize immigration and asylum policies together with the European Union. Through the Schengen Agreement in 1985, the five European Commission Member States (Belgium, the Netherlands, Luxembourg, Germany and France) worked together in controlling internal borders and revising visa granting provisions.

This regulation shows that the level of education of immigrants and the next generation of immigrants in France is still a problem even to this day. In 1981, Alain Savary, French Minister of Education initiated Zones d'ÉducationPrioritaire (ZEP), priority education zones as one of the efforts to integrating immigrants in France. ZEP combat inequality of education, school failures and accommodate immigrants students. [7] Sadly, ZEP was consider fail due to their social situation than their ethnic origin. Besides the education domain, to fight against the isolation of disadvantaged neighborhoods, Jacques Barrot, Secretary of State for Housing, installs the first suburban plan, banlieue. Banlieue focuses on building a large place to live for immigrants, unfortunately banlieue was seen as slums, public housing, crime, where impoverished non-European immigrant communities is concentrated there. [17] Banlieueaims to provide immigrants coexist with French society, but this worsen the case, the social segregation was more visible than ever, making the immigrants hard to integrate with "French society." The existence of ZEP and banlieue today marked as an identity of immigrants and their generation to come. The immigrant's identity was seen as a low class and uneducated people, which hampered their integration progress into French society.

\subsection{Regulation of September 1986, La LoiPasqua}

During the Mitterrand administration, there was a period of cohabitation, an institutional co-existence between the head of state and the leadership of the government (anticipation of antagonistic politics) due to the RPR and UDF, right-wing political parties that won a majority in the legislative elections. The first cohabitation period marked by "La LoiPasqua", which prevented the naturalization and integration of African immigrants, adding the naturalization process time from one year to two years. The impact of La LoiPasqua seen between 1993 and 1999, when less than 100,000 people migrated annually to France. As a result, there has been an increase in the number of immigrants, more than 12,000 people were arrested in trying to enter France illegally. [9] The purpose of la loiPasqua is l'immigration zero, which aims to control the inflow of immigrants, not only to stop the number of immigrants coming to France but to try repatriating immigrants who had already arrived in France. [16] This policy shows the different characteristics between left-wing politics and right-wing politics and the aims of this policy do not align with the Socialists. Despite more than thirty years efforts that aim to control and reduce immigration, the number of immigrants who regularly come to France does not weaken. The education, integration and stereotyping remain an unsolved problem.

\subsection{Regulation of August 1989, La LoiJoxe}

Opposition figure, Michel Rocard criticized La LoiPasqua for being intolerant to immigrants. Through this criticism La LoiPasqua made legislative changes on August $2^{\text {nd }}$, 1989 known as La LoiJoxe which created a new guarantee for immigrants by giving residence card and gives protection to immigrants who had family in France; even adding security guarantees and reconsidering deportations against illegal immigrants. [7]

In the $1990 \mathrm{~s}$, family migration became more strict than before, the regularization program banishes family members who entered France illegally. Even though family members are not 
deported because of the right to family life, they cannot change their illegal status. When the 1997-1998 regularization program aims to provide legal status, the number of immigrants from Algeria, Morocco and Tunisia increased in the censuses of 1982, 1990 and 1999. [5]

During this period, the left-wing government restrict regulations on family migration to reduce the number of immigrants entering France. The attitude of the socialist government tends not to impose deportation on immigrants, but their existence in France is complicated by the government. This regulation seems to repeat the policies that have been applied before but in a more assertive attitude. It can be said that the period of cohabitation influenced the socialist style of government which took part in forceful action. Also, La LoiJoxe helps immigrants find decent jobs. Research by Barou in 2014 showed that since the early 1980s, the unemployment rate has never been lower than $7 \%$ and then increased due to the influx of maghreb immigrants who are considered to be of poor quality. [10]

From 1986 to 1989, the left-wing government gives opportunities to young people to work at low wages and the employers are free from paying contributions through the TUC (Travauxd'Utilité Collective) policy and the SIVP (Stage d'Initiation à la Vie Professionnelle) policy. In 1989 the CES (ContratsEmploi-Solidarite) policy was carried out to help young people find permanent employment. Also, contrat de qualification-jeunes allows employers to recruit young people and pay them between 30 and $60 \%$ of the SMIC (Salaire Minimum Interprofessionnel de Croissanceor minimum wage).

\subsection{Regulation of December 1991}

This regulation focused on fighting illegal immigrant workers, by deporting more than 30,000 illegal immigrants. The left-wing government provides social protection for illegal immigrants and the right to marry if they have a place to live in France. An example of an effort to integrate immigrants is La Loi Anti-Ghetto on July 13th, 1991 which gives housing access for immigrants to reduce the phenomenon of discrimination and social segregation in suburban life. On September 26th, 1991 revoked the right to work for refugees. [7]

\subsection{Regulation of July 1992, La LoiQuilès}

Then Regulation No. 92-625 on July 2nd, 1992, known as La LoiQuilès by Paul Quilès, left-wing political figure. La LoiQuilès retains illegal immigrants and refugees that are not permitted to enter French territory in the "zones d'attente" around the port and airport for up to 20 days. [11]

\subsection{Regulation of August 1993, La LoiPasqua the second}

In March 1993, the parliamentary elections the RPR-UDF opposition parties won the most votes, thus marked a second period of cohabitation. Since then, only political réfugiéeshave been allowed into France. The Regulation of August 24th, 1993 or the second La LoiPasqua, introduces the right to family reunion (regroupement familial) aimed at preventing immigrants from settling and hold social rights such as health care. As a result, it is difficult for immigrants to bring their families, due to new legal conditions relating to income and housing. This policy also makes it difficult for immigrants to obtain French citizenship who marry French citizens by increasing marriage time from a minimum of six months to two years. [1]

Then La LoiGuigou was present to loosen La LoiPasqua by allowing all peoplewho's born in French territory to apply for naturalization. The naturalization process is rarely rejected and around $80 \%$ succeed in gaining French citizenship. This resulting to more and more immigrant children after the age of 16, who have French citizens increased by $32 \%$ in 1994 and $43 \%$ in 1995. Then, this regulation was abolished by the Socialist Government in November 1997. [6] 
Through a report published by the High Council for Integration (HCI) in 2011, French citizens whose parents migrated from non-European countries were twice as likely $(24.2 \%)$ to be unemployed compared to other citizens. These figures indicate that racial discrimination affects certain categories of French citizens. There is no doubt that the integration of immigrants and their descendants into French society has become more difficult. [11]

This shows that immigrants consider themselves as victims of racial discrimination because of their ethnic origin, their religion or their place of residence. Naturalization and equal rights do not guarantee a successful integration. Differences in race, culture, and skin color lead to negative stereotypes that aimed immigrants. [8] Negative stereotypes trigger discriminatory actions that make it harder for them to get a job and their conditions deteriorate over time as the number of unemployed French continues to rise.

Besides, Maghreb immigrants in France labeled "Muslims" are considered not "genuine" French citizens. During the 1970s and early 1980s, the French Republic took a relatively tolerant attitude around cultural and religious differences, then François Mitterrand came up with the slogan droit à la difference. However, many French conservatives in the early 1980s criticized the leftist government as a carrier of social unrest and the existence of Muslims was incompatible with the values of French laïcité. As a result, President Mitterrand began promoting Islam de France (French Islam) to combine and nurture "Muslims" and make room for French Islamic organizations. [12] However, Mitterrand's efforts to promote Islam in France remained unsuccessful due to the many differences in French values as a secular state and Islam which was considered a closed religion.

The inconsistent regulation that goes back and forth on keeping and banishing the immigrants during the François Mitterrand's reign makes it harder to control the immigration flow, which later made the integration process difficult to do. Even the present-day President, Emmanuel Macron, still continues Mitterrand's idea, Islam de France to integrate the Muslims in France.

\section{CONCLUSION}

The need for foreign workers in France increases the number of incoming immigrants, especially immigrants from the Maghreb, which then triggers integration problems. The integration problem in France is interesting because until this day, it has not been resolved, therefore it is necessary to see how migration policies especially in the 1980s when Francois Mitterrand served as the first Socialist President in France. In implementing the migration policy, the Socialist government tolerates the presence of immigrants more than the right-wing government, which tends to be more conservative. This was seen during cohabitation. The involvement of right-wing political figures during the cohabitation period influenced the gesture of the Socialist government that became more drastic. The gesture was seen through the 1997-1998 regularization program which was more stringent than in 1981. The integration efforts of the Mitterrand government are more focused on the younger generation of immigrants by giving them remissions and opportunities to work and get higher education. Unfortunately, the remissions made things worse, the number of illegal immigrants was increasing. It can be said that the remission does not seem to consider the long-term impact of the future conditions of France and merely just to equalize human rights. Through the above explanation, the benchmarks of Mitterrand's success in his efforts to integrate immigrants in France was considered unsuccessful. After Mitterrand's reign, France still unresolved social problem such as racial discrimination, unemployment and low quality of human resources 
making the immigrants condition in France is deteriorated, made the integration process more difficult.

\section{REFERENCES}

[1] F. H and D. S, "The Integration of Immigrants in European Societies: National Differences," Lucius \& Lucius DE, 2016.

[2] A. Cole, "Studying Political Leadership: The Case of François Mitterrand," Political Studies, vol. 42, (3), pp. 453-468, 2018.

[3] W. E. Hanson et al, "Mixed Methods Research Designs in Counseling Psychology," Journal of Counseling Psychology, vol. 52, (2), pp. 224-235, 2005.

[4] R. Tiersky, "Mitterrand's Legacies," Foreign Affairs, vol. 74, (1), pp. 112-121, 1995. DOI: $10.2307 / 20047023$.

[5] M. DeLey, "French Immigration Policy Since May 1981," International Migration Review, vol. 17, (2), pp. 196, 1983.

[6] INSEE, module complémentaire à l'enquêteEmploi sur la mobilité, les compétencesetl'insertionprofessionnelle (2014).

[7] D. Lochak. "Les socialistes et l'immigration, 1981-1993." Olivier Le CourGrandmaison; Catherine Wihtol de Wenden. Les étrangersdans la cité. Expérienceseuropéennes, La Découverte, pp. 43-63, 1993, 2-7071-2284-X. ffhal01698331

[8] R. Ade Saputra. "KondisiSosial-EkonomiPekerjaImigranMagribi Di PrancisPada Masa Pemerintahan Nicolas Sarkozy". Universitas Indonesia, Depok. 2016

[9] J. F. Hollifield, "The Emerging Migration State," The International Migration Review, vol. 38, (3), pp. 885-912, 2004.

[10] J. Barou, "Integration of immigrants in France: a historical perspective," Identities, vol. 21, (6), pp. 642-657, 2014.

[11] Plathner, C. Plathner. "EU immigration and asylum policy from the perspective of regime complexity." Lund University, Department of Political Science. 2013.

[12] N. Fellag "The Muslim Label: How French North Africans Have Become "Muslims" and not "Citizens".’Journal on Ethnopolitics and Minority Issues in Europe. 2014

[13] L. Block and S. Bonjour, "Fortress Europe or Europe of Rights? The Europeanisation of Family Migration Policies in France, Germany and the Netherlands," European Journal of Migration and Law, vol. 15, (2), pp. 203-224, 2013.

[14] J. Birch. "The Many Lives of François Mitterrand" 2015. Access from:https://www.jacobinmag.com/2015/08/francois-mitterrand-socialist-partycommon-program-communist-pcf-1981-elections-austerity/

[15] W. Lignier and J. Pagis, ""Left" vs. "right": how french children reconstruct the political field," American Behavioral Scientist, vol. 61, (2), pp. 167, 2017.

[16] M. Harzoune "Qu'est-ce que "l'immigrationzéro" ?". 2012 Access from:https://www.histoire-immigration.fr/questions-contemporaines/politique-etimmigration/qu-est-ce-que-l-immigration-zero

[17] N. Roussellier, "Berstein Serge, La France des années 30. Becker jean-Jacques, Histoire politique de la France depuis 1945, Eck Jean-François, Histoire de l'économiefrançaisedepuis 1945 Borne Dominique, Histoire de la sociétéfrançaisedepuis 1945," Vingtième Siècle. Revue d'Histoire, vol. 21, (1), pp. 146-147, 1989. 